\title{
REGIONAL INCOME DISPARITIES IN CANADA: IMPLICATIONS FOR THEORIES OF REGIONAL CONVERGENCE
}

\author{
Elias G. Carayannis and Rajiv Mallick*
}

\begin{abstract}
Traditional regional convergence theory has come under serious scrutiny in view of the recent divergence in regional incomes in the U.S. during the eighties. Neither the neoclassical theory of a steady decline in regional disparities over time nor Kuznets' inverted-U hypothesis can satisfactorily explain regional divergence in an advanced industrial nation. Alternative theories that emphasize spatial restructuring of economic activity have been offered to explain rising regional inequality in the U.S. In this paper, we caution against a hasty approach to new theorizing based on the U.S. experience alone. We study the Canadian experience with regional economic convergence to see how, if at all, it parallels the experience of the United States, Europe, and Australia, with respect to regional growth. By examining provincial data at the industry level, we seek to detect if there are any leading sectors of spatial concentration as in the U.S.

We find that, unlike the U.S., European, and Australian experience, Canada has been characterized by consistent, albeit gradual, economic convergence, including in the 1980s. No leading sectors of regional importance emerge, but based on available data, federal programs of regional equalization may be at least partly responsible for continued regional convergence in Canada.
\end{abstract}

\section{INTRODUCTION}

The issue of what happens to income differentials over time in a given country has been of interest from both a theoretical and a public policy perspective. Empirical research on regional income convergence has traditionally been inspired by either neoclassical theory (Smith 1975; McCombie 1988; Reid 1989) which predicts movement towards an equilibrium state of regional income equality, or Kuznets' (1955) inverted-U hypothesis, which also predicts declining regional income disparities, albeit in the latter stages of economic development.

Recent findings suggest that regional income disparities have increased in mature economies, like the United States (Amos 1989,1991; Braun 1991; Coughlin and Mandelbaum 1988), regions of Europe (Barro and Sala-i-Martin 1991), and Australia (Maxwell and Hite 1992). This evidence has provoked new hypotheses of regional development that emphasize spatial restructuring due to international competition (Fan and Cassetti 1994), regional concentration of new leading sectors (for example, communications) in the traditional growth centers (Amos 1991), and the importance of economies of scale and transportation costs

*Assistant Professor, Management Science Department, School of Business and Public Management, George Washington University, and Pracon Econometrics, respectively. 
in producing urban agglomerations (Krugman 1993). The upward divergence of the Northeast and California during the 1980s, for example, is attributed to a sectoral shift to high technology industries located in these states (Barff and Knight 1988; Coughlin and Mandelbaum 1988; Lampe 1988).

Before discarding the traditional view of convergent regional dynamics for hypotheses that emphasize re-polarization of economic activity, one needs to examine the experience of other mature economies. If the re-polarization of economic activity in the United States is a general characteristic of advanced economies, it may have been paralleled by other countries at a similar stage of development. If, on the other hand, the U.S. experience represented special political and social factors such as the defense build-up and the regionally differential impact of related investments in technology and research, it may have been unique to this country. We examine the regional economic dynamics of another mature economy, Canada, to help provide an answer.

Canada provides an interesting case study of trends in regional economic disparities for an additional reason. Canada is unique in that regional economic equalization has been recognized as an explicit federal policy goal. In the United States, by contrast, regional equalization is recognized as a social objective only to the degree that the federal contribution to states for Medicaid is based on per capita income for the state. The same is true of federal contributions to localities for development programs. ${ }^{1}$

In the rest of this paper, we examine trends in inter-provincial income disparities in Canada over the last three decades. In the second section, we present an overview of the measures of regional income disparity estimated in this study. The third section presents the results of our empirical analysis and our inferences on regional convergence of economic activity in Canada. We further present estimates of convergence disaggregated by major industrial activity. In the fourth section, we offer a discussion of unique public policy factors in Canadian regional dynamics-federal transfers to provinces for regional equalization and federally initiated regional economic development initiatives. We present some evidence on provincial differentials in investments in transportation infrastructure and its impact on productivity growth differentials across provinces. The fifth section offers concluding remarks. 


\section{METHODOLOGY}

\section{Measures of Regional Income Disparities}

Several measures of regional income disparity have been used in the literature. We estimate a representative set of these measures.

A simple measure of regional disparity is the vector of PPCIs, i.e., the percent of per capita income in a province to the nation (Friedenberg 1978; Garnick \& Friedenberg 1982; Garnick 1990).

\section{$\mathrm{PPCI}_{\mathrm{i}, \mathrm{t}}=\mathrm{GDPC}_{\mathrm{i}, \mathrm{t}} / \mathrm{GDPC}_{\mathrm{Can}, \mathrm{t}}$}

where GDPC $_{i, t}$ is per capita income in province $i$ at time $t$ and GDPC $_{C a n, t}$ is Canadian per capita income at time $t$. The greater the divergence of the elements of this vector from one, the greater the inter-province economic disparity at a moment in time. We estimate this vector at different points in time to measure the change in regional inequality over time.

In contrast to the PPCI, which is a vector measure, the remaining measures of regional disparity have the advantage of providing scalar values. The first such measure is the weighted coefficient of income variation (Vw) (Amos 1989).

$$
\mathrm{V}_{\mathrm{w}, \mathrm{t}}=\left[\Sigma\left(\mathrm{GDPC}_{\mathrm{i}, \mathrm{t}}-\mathrm{GDPC}_{\mathrm{Can}, \mathrm{t}}\right)^{2} *\left(\mathrm{POP}_{\mathrm{i}, \mathrm{t}} / \mathrm{POP}_{\mathrm{Can}, \mathrm{t}}\right)\right] / \mathrm{GDPC}_{\mathrm{Can}, \mathrm{t}}
$$

where $\mathrm{POP}_{i, t}$ is the population of province $\mathrm{i}$ in time $\mathrm{t}$ and $\mathrm{POP}_{\mathrm{Can}, \mathrm{t}}$ is the population of Canada in time $t$.

A second summary measure of regional disparity is derived from Theil's entropy measure of industrial concentration. This information-theoretic measure has been applied in earlier work to measurement of regional income disparities $\left(\mathrm{J}_{\mathrm{c}}\right)$ (Fan and Cassetti 1994; Nissan \& Carter 1993):

$$
\mathrm{J}_{\mathrm{c}, \mathrm{t}}=(1 / \mathrm{n}) * \Sigma\left[\left(\mathrm{POP}_{\mathrm{i}, \mathrm{t}} / \mathrm{POP}_{\mathrm{Can}, \mathrm{t}}\right) /\left(\mathrm{GDP}_{\mathrm{i}, \mathrm{t}} / \mathrm{GDP}_{\mathrm{Can}, \mathrm{t}}\right)\right],
$$

where $\mathrm{GDP}_{\mathrm{i}, \mathrm{t}}$ is the gross domestic product for province $\mathrm{i}$ in time $\mathrm{t}$ and GDPCan,t is the gross domestic product for Canada in time $t$. If all provinces have the same GDP per capita $\left(G P_{i, t} / P P_{i, t}\right)$, then it is easily seen that $J_{c, t}=1$. With less than perfect equality of provincial per capita incomes, $\mathrm{J}_{c, t}<$ or $>1$.

We further decompose the entropy measure of regional income disparity into a component reflecting regional disparity in employment rates $\left(\mathrm{J}_{e}\right)$ and a component reflecting regional disparity in GDP per worker $\left(\mathrm{J}_{\mathrm{w}}\right)$ : 


$$
\begin{aligned}
& \mathrm{J}_{c, t}=(1 / n) * \Sigma\left[\left\{\left(\mathrm{POP}_{\mathrm{i}, \mathrm{t}} / \mathrm{POP}_{\mathrm{Can}, \mathrm{t}}\right) /\left(\mathrm{EMP}_{\mathrm{i}, \mathrm{t}} / \mathrm{EMPCan}, \mathrm{t}\right)\right\} *\right. \\
& \left\{\left(\mathrm{EMP}_{\mathrm{i}, \mathrm{t}} / \mathrm{EMPCan}, \mathrm{t}\right) /\left(\mathrm{GDP}_{\mathrm{i}, \mathrm{t}} / \mathrm{GDP}_{\mathrm{Can}, \mathrm{t}}\right)\right\} \text { ], }
\end{aligned}
$$

where $\mathrm{EMP}_{\mathrm{i}, \mathrm{t}}$ is total employment for province $\mathrm{i}$ in time $\mathrm{t}$ and EMPCan,t is total employment for Canada in time $t$.

If all provinces had the same employment rate, ER, where $\mathrm{ER}=\mathrm{EMP}_{\mathrm{i}, \mathrm{t}} / \mathrm{POP}_{\mathrm{i}, \mathrm{t}}$, then substituting a common ER into 43) yields:

$\mathrm{J}_{\mathrm{c}, \mathrm{t}}=(1 / \mathrm{n}) * \Sigma\left[\left(\mathrm{EMP}_{\mathrm{i}, \mathrm{t}} / \mathrm{EMPCan}, \mathrm{t}\right) /\left(\mathrm{GDP}_{\mathrm{i}, \mathrm{t}} / \mathrm{GDP}_{\mathrm{Can}, \mathrm{t}}\right)\right]=\mathrm{J}_{\mathrm{w}, \mathrm{t}}$.

In other words, with common ERs, inter-province differences in per capita income $\left(\mathrm{J}_{\mathrm{C}}\right)$ would be entirely attributable to inter-provincial differences in income per worker $\left(J_{W}\right)$. On the other hand, if all provinces have the same GDP per worker (GDP $\mathrm{G}_{\mathrm{i}, \mathrm{t}} / \mathrm{EMP}_{\mathrm{i}, \mathrm{t}}$ or worker productivity), then:

$$
\mathrm{J}_{\mathrm{c}, \mathrm{t}}=(1 / \mathrm{n}) * \Sigma\left[\left(\mathrm{EMP}_{\mathrm{i}, \mathrm{t}} / \mathrm{EMPCan}, \mathrm{t}\right) /\left(\mathrm{GDP}_{\mathrm{i}, \mathrm{t}} / \mathrm{GDP}_{\mathrm{Can}, \mathrm{t})}\right]=\mathrm{J}_{\mathrm{e}, \mathrm{t}} .\right.
$$

Now, all inter-province disparity in per capita income is attributable to differences in employment rates across the provinces.

A final measure of regional income disparity is the dissimilarity index based on the Lorenz curve (D) (Fan \& Casetti 1994):

$$
D_{t}=(1 / 2) * \Sigma\left[\left(G D P C_{i, t} / G D P C_{C a n, t}\right)-\left(P P_{i, t} / P_{C P}, t\right)\right]
$$

\section{Trends in Regional Disparity: A Goodness-of-Fit Approach}

In order to characterize time trends in inter-province income disparity in greater detail, we supplement our analysis above with a classification (goodnessof-fit) approach. First, we classify provinces by their economic levels at an initial period. We then cross-classify the provinces by whether provinces at above (below) average initial levels exhibited below or above average growth over the period. With regional convergence, we expect most provinces to display an inverse relationship between initial economic well-being and economic growth. Consequently, in the associated contingency table, most provinces should lie in cells that are consistent with this relationship. ${ }^{2}$ 


\section{Regional Inequality by Major Industrial Activity}

In order to assess the relative importance of specific industries, and to identify any leading sectors of polarization (regional divergence), we also estimate the $\mathrm{J}_{\mathrm{c}}$ measure of regional disparity for each industry over time. Second, industrylevel PPCIs are computed for each province over time. The paper presents an overview of the top and bottom provinces in terms of PPCI in each industry in 1966 and 1992.

\section{DATA AND FINDINGS}

Data for our study came from published reports of Statistics Canada (1993, 1994) and unpublished reports of the Conference Board of Canada (1994). In order to analyze trends in inter-provincial disparity over time in Canada, we obtained annual data on GDP, population, and employment for each of the Canadian provinces. ${ }^{3}$ Data on the first two indicators were available beginning with 1961 and for employment beginning with 1969. We further obtained data on GDP and employment by major industry for each province; these data are generally available only for years subsequent to 1975 .

We first attempt to get an overview of trends in regional income disparities in Canada. To do so, we calculate the three regional disparity indices: (a) $\mathrm{J}_{\mathrm{c}}$ (and its components $J_{w}$, and $J_{e}$ ), (b) $V_{w t}$ and (c) $D_{t}$ for each year beginning with 1969.

The results are reported (by 5-year intervals for brevity) in Table 1 and plotted in Figure 1 (Panels A,B and C). The declining values of all three indices of regional income disparity over time indicate that the predominant tendency of the Canadian provinces is economic convergence.

The decomposition of the entropy measure of income disparity shows that provincial disparity in employment rates, $\mathrm{J}_{\mathrm{e}}$, has remained fairly stable, as shown in Figure 1 (Panel A). This means that almost all of the decline in provincial income disparity $\left(\mathrm{J}_{\mathrm{c}}\right)$ was due to a decline in provincial differentials in GDP per worker, i.e., productivity $\left(\mathrm{J}_{\mathrm{w}}\right)$, while inter-provincial inequality in the employment rate has remained fairly constant. Differences across provinces in the employment rate are of course further decomposable into provincial differentials in unemployment rates and provincial differentials in labor force participation (LFP) rates. Mansell and Copithome (1986) have shown that an increase of provincial differences in unemployment rates in Canada has been approximately offset by a decrease in LFP differentials across provinces. ${ }^{4}$

Clearly, the Canadian provincial economies have converged over the last $\mathbf{3 0}$ years. In order to better identify economic convergence trends in each decade, we 
TABLE 1

Trends in Inter-Province Economic Disparities in Canada

\begin{tabular}{lccccc}
\hline \hline YEAR & \multicolumn{3}{c}{$\begin{array}{c}\text { Modified } \\
\text { Entropy } \\
\text { Measures }\end{array}$} & $\begin{array}{c}\text { Weighted } \\
\text { Coefficient } \\
\text { of Variation }\end{array}$ & $\begin{array}{c}\text { Dissimilarity } \\
\text { Index }\end{array}$ \\
\hline & $\mathrm{J}_{c}$ & $\mathrm{~J}_{\mathrm{e}}$ & $\mathrm{J}_{\mathrm{w}}$ & $\mathrm{V}_{\mathrm{w}}$ & $\mathrm{D}$ \\
\hline 1961 & 1.335 & NA & NA & 0.2022 & 0.0857 \\
1966 & 1.304 & 1.087 & 1.180 & 0.1851 & 0.0766 \\
1971 & 1.294 & 1.088 & 1.173 & 0.1787 & 0.0763 \\
1976 & 1.260 & 1.090 & 1.134 & 0.1855 & 0.0747 \\
1981 & 1.274 & 1.092 & 1.140 & 0.2277 & 0.0819 \\
1986 & 1.224 & 1.093 & 1.109 & 0.1553 & 0.0651 \\
1989 & 1.248 & 1.087 & 1.136 & 0.1506 & 0.0469 \\
1992 & 1.203 & 1.085 & 1.088 & 0.1139 & \\
\hline
\end{tabular}

disaggregate the last 30 years accordingly. For each decade, and for the entire 1989-92 period, we classify provinces by their initial per capita income relative to the Canadian average and their relative income growth in the corresponding decade. Table 2 is the resultant contingency table. During the 1961-92 period, eight of the ten Canadian provinces included in our study converged. All the Atlantic provinces, Saskatchewan, and Quebec, were upwardly convergent; Ontario and British Columbia were downwardly convergent. Only Manitoba was downwardly divergent and only Alberta was upwardly divergent.

During the 1960s, as many as nine out of the ten provinces in the study displayed evidence of economic convergence. The exception was Manitoba, which was downwardly divergent. The 1970 s were characterized by relatively mixed evidence on regional convergence. As many as five states were now divergent. During the 1980s, the Canadian provinces converged again, with the exception of Ontario, which diverged upwards.

\section{Estimates of Regional Convergence by Industrial Activity}

We use data on GDP by industry for each province (available since 1975) to obtain measures of regional income differences by major industrial activity. Two techniques based on two different measures of regional disparity are used to describe the regional dynamics by industry. The first method, based on the PPCI, compares provinces in terms of their ranking in each industrial activity. Thus we are able to identify if and how the traditional "growth poles" for each industry have retained their relative dominance over the years. Second, we compute $\mathrm{J}_{\mathrm{c}}$ for each industry as a rigorous test of the changes in regional differentials in productivity by major activity. 


\section{FIGURE 1}

PANEL A: Entropy Measures of Disparity: Income, Empl. Rate

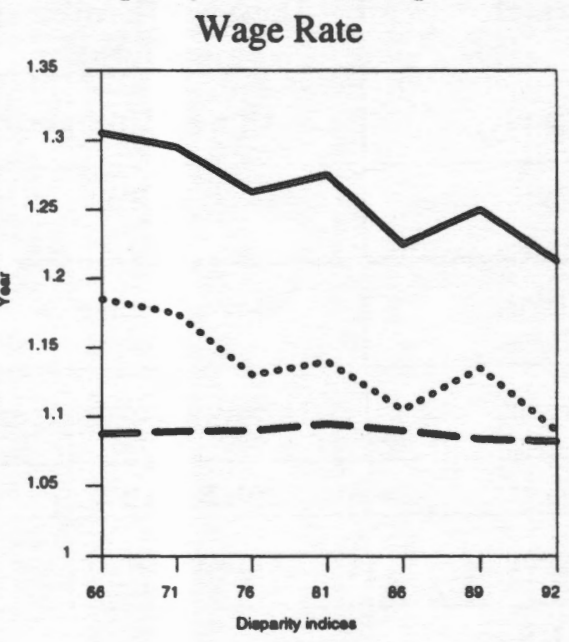

PANEL B: Provincial Disparities: Weighted Coefft. of Variation

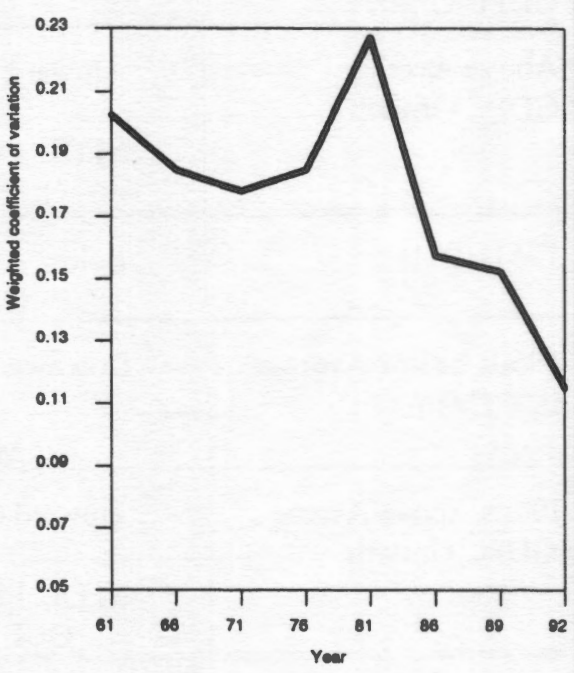
Prov. wage dieperity

PANEL C: Provincial Disparities:

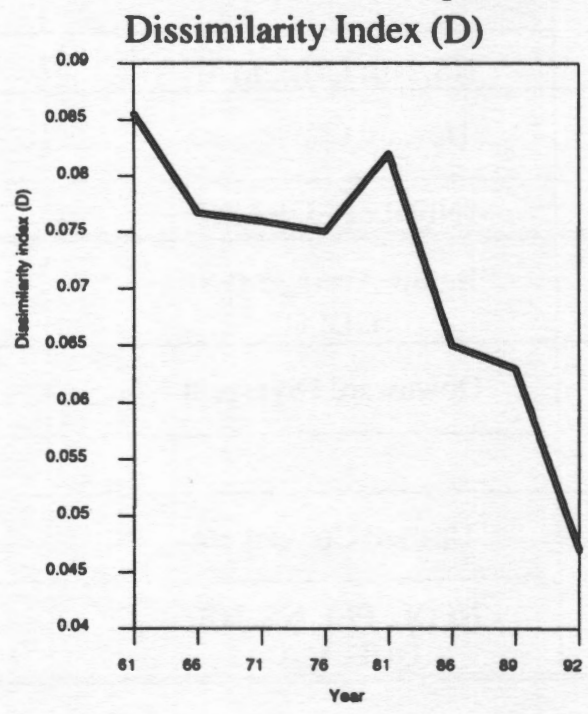


TABLE 2

Regional Economic Convergence in Canada: A Cross-Classification Table

\begin{tabular}{|c|c|c|}
\hline $\begin{array}{l}\text { 1961-1992 } \\
\text { (Sample Period) }\end{array}$ & $\begin{array}{c}\text { Below Average } 1961 \\
\text { GDPC }\end{array}$ & $\begin{array}{c}\text { Above Average } 1961 \\
\text { GDPC }\end{array}$ \\
\hline $\begin{array}{l}\text { Below Average } \\
\text { GDPC Growth }\end{array}$ & $\begin{array}{c}\text { Downward Divergent } \\
\text { MAN }\end{array}$ & $\begin{array}{c}\text { Downward Convergent } \\
\text { ONT, BC } \\
\end{array}$ \\
\hline \multirow{2}{*}{$\begin{array}{l}\text { Above Average } \\
\text { GDPC Growth }\end{array}$} & Upward Convergent & Upward Divergent \\
\hline & $\begin{array}{c}\text { NFDL, PEI, NS, NB, } \\
\text { QUE, SASK }\end{array}$ & ALTA \\
\hline $1961-1971$ & $\begin{array}{c}\text { Below Average } 1961 \\
\text { GDPC }\end{array}$ & $\begin{array}{c}\text { Above Average } 1961 \\
\text { GDPC }\end{array}$ \\
\hline \multirow{2}{*}{$\begin{array}{l}\text { 1960s Below Average } \\
\text { GDPC Growth }\end{array}$} & Downward Divergent & Downward Convergent \\
\hline & MAN & ONT, ALTA, BC \\
\hline \multirow{2}{*}{$\begin{array}{l}\text { 1960s Above Average } \\
\text { GDPC Growth }\end{array}$} & Upward Convergent & Upward Divergent \\
\hline & $\begin{array}{c}\text { NFDL, PEI, NS, NB, } \\
\text { QUE, SASK } \\
\end{array}$ & \\
\hline 1971-1981 & $\begin{array}{c}\text { Below Average } 1971 \\
\text { GDPC }\end{array}$ & $\begin{array}{c}\text { Above Average } 1971 \\
\text { GDPC }\end{array}$ \\
\hline \multirow{2}{*}{$\begin{array}{l}\text { 1970s Below Average } \\
\text { GDPC Growth }\end{array}$} & Downward Divergent & Downward Convergent \\
\hline & NS, NB, QUE, MAN & ALTA, ONT \\
\hline \multirow{2}{*}{$\begin{array}{l}\text { 1970s Above Average } \\
\text { GDPC Growth }\end{array}$} & Upward Convergent & Upward Divergent \\
\hline & NFDL, PEI, SASK & BC \\
\hline 1981-1992 & $\begin{array}{c}\text { Below Average } 1981 \\
\text { GDPC } \\
\end{array}$ & $\begin{array}{l}\text { Above Average } 1981 \\
\text { GDPC }\end{array}$ \\
\hline \multirow{2}{*}{$\begin{array}{l}\text { 1980s Below Average } \\
\text { GDPC Growth }\end{array}$} & Downward Divergent & Downward Convergent \\
\hline & & SASK, ALTA, BC \\
\hline \multirow{2}{*}{$\begin{array}{l}\text { 1980s Above Average } \\
\text { GDPC Growth }\end{array}$} & Upward Convergent & Upward Divergent \\
\hline & $\begin{array}{l}\text { NFDL, PEI, NS, NB, } \\
\text { QUE, MAN }\end{array}$ & ONT \\
\hline
\end{tabular}

Note: ALTA = Alberta; $B C=$ British Columbia; $M A N=$ Manitoba; NB = New Brunswick;

NFDL = Newfoundland; NS = Nova Scotia; ONT = Ontario; PEI = Prince Edward Island; QUE = Quebec; SASK = Saskatchewan. 


\section{Traditional Poles of Industrial Activity: Dominance over Time}

We first computed the PPCI for each province for each industry for the two polar years, 1971 and 1992. We then ranked the provinces in descending order of their PPCI in each industry. On the basis of these rankings, we identify the two provinces that ranked at the top and bottom in terms of their PPCI in a given industry in 1971. We then see how these same provinces were ranked in 1992. In Table 3, we present these two provinces for 1971 for each industrial activity. For example, Saskatachewan ranked first and Newfoundland ranked last in PPCI for Agriculture and Forestry in 1971; the former had a per capita agricultural income that was about 4.5 times the Canadian average, while Newfoundland had an agricultural per capita income that was only about 28 percent of the Canadian average. As can be seen, these two provinces preserved their respective rankings in 1992, although the agricultural PPCI of Saskatchewan increased from 450 percent to 550 percent.

It is interesting that for only three industries-Construction, Wholesale Trade, and Public Administration and Defense-was there any significant realignment of provinces based on their relative productivity rankings between 1971 and 1992. However, even though PPCI rankings of the provinces at either end of the spectrum did not change for many other industries, their PPCI ratios did. For example, the per capita income gap in Finance between top-ranked Alberta and bottom-ranked Newfoundland had closed from a ratio of $2.6(1.44 / 0.56)$ to 2.1 (1.29/0.62) between 1971 and $1992 .{ }^{5}$ A similar observation may be made for the same two provinces with respect to manufacturing activity (Goods-Producing Industries).

\section{Changes in the Regional Productivity Differentials by Industry}

In Table 4 we present the findings on regional income inequality based on the modified entropy measure $\left(J_{c}\right)$ for the years $(t) 1969,1971,1976,1981,1986$, 1989, and 1992 for each industry.

Based on the $\mathrm{J}_{c}$ values for each industry presented in Table 4, we may summarize our major findings and implications as follows:

- There is virtually no convergence in the "primary" or "natural-resourcebased" industries-Agriculture \& Forestry, Fishing, and Mining. Indeed, regional inequality increased in these industries, especially in the 1970s and early 1980's before declining somewhat in the late 1980s and early $1990 s^{6}{ }^{6}$ The non-convergence of per capita income within these sectors is consistent with our expectations since, by definition, these industries 
TABLE 3

Topology of Provinces by Relative Productivity and by Industry (PPCI)

\begin{tabular}{|c|c|c|c|c|}
\hline \multirow{3}{*}{$\begin{array}{l}\text { Province / PPCI } \\
\text { Agriculture \& } \\
\text { Forestry }\end{array}$} & \multicolumn{2}{|c|}{$\begin{array}{c}\text { First \& Last Province In } \\
1971 \text { PPCI }\end{array}$} & \multicolumn{2}{|c|}{$\begin{array}{c}1992 \text { Rank Of First \& } \\
\text { Last Province In } 1971 \\
\text { PPCI }\end{array}$} \\
\hline & SASK (1) & 4.49 & SASK (1) & 5.49 \\
\hline & NFDL (10) & 0.28 & NFDL (10) & 0.27 \\
\hline \multirow[t]{2}{*}{ Fishing } & PEI (1) & 7.66 & PEI (1) & 9.66 \\
\hline & ALTA (10) & 0.13 & ALTA (9) & 0.15 \\
\hline \multirow[t]{2}{*}{ Mining } & ALTA (1) & 7.39 & ALTA (1) & 6.63 \\
\hline & PEI (10) & 0.01 & PEI (10) & 0.00 \\
\hline \multirow[t]{2}{*}{ Construction } & ALTA (1) & 1.31 & $\operatorname{ALTA}(2)$ & 1.33 \\
\hline & PEI (10) & 0.68 & PEI (5) & 0.90 \\
\hline \multirow{2}{*}{$\begin{array}{l}\text { Transportation \& } \\
\text { Communications }\end{array}$} & MAN (1) & 1.31 & MAN (1) & 1.36 \\
\hline & NS (10) & 0.64 & NS (9) & 0.77 \\
\hline \multirow[t]{2}{*}{ Wholesale Trade } & $\mathrm{BC}(1)$ & 1.25 & $\mathrm{BC}(3)$ & 1.05 \\
\hline & NB (10) & 0.58 & NB (8) & 0.71 \\
\hline \multirow[t]{2}{*}{ Finance } & ALTA (1) & 1.44 & ALTA (1) & 1.29 \\
\hline & NFDL (10) & 0.56 & NFDL (10) & 0.62 \\
\hline \multirow[t]{2}{*}{ Services } & ALTA (1) & 1.14 & ALTA (1) & 1.31 \\
\hline & NFDL (10) & 0.63 & NFDL (10) & 0.72 \\
\hline \multirow{2}{*}{$\begin{array}{l}\text { Public Admin. \& } \\
\text { Defense }\end{array}$} & NS (1) & 1.7 & NS (1) & 1.55 \\
\hline & NFDL (10) & 0.62 & NFDL (7) & 1.06 \\
\hline \multirow{2}{*}{$\begin{array}{l}\text { Goods Producing } \\
\text { Industries }\end{array}$} & ALTA (1) & 1.86 & ALTA (1) & 1.62 \\
\hline & NFDL (10) & 0.46 & NFDL (10) & 0.54 \\
\hline \multirow{2}{*}{$\begin{array}{l}\text { Total For All } \\
\text { Industries }\end{array}$} & ALTA (1) & 1.56 & ALTA (1) & 1.22 \\
\hline & PEI (10) & 0.54 & PEI (1) & 0.71 \\
\hline
\end{tabular}

Note: See Table 2 for explanation of acronymns.

are relatively immobile across space; therefore, regional differentials are not expected to narrow over time in the absence of diversification of the resource-based economies. ${ }^{7}$

- There is some convergence in manufacturing GDPC, as evidenced by a consistent decline in the regional inequality index for Goods Producing Industries. ${ }^{8}$ This evidence is consistent with an earlier finding that in the 1961-75 period, the Atlantic states witnessed highest rates of produc- 
TABLE 4

Analysis of Regional Income Inequality by Industry $\left(\mathrm{J}_{\mathrm{C}}\right)$

\begin{tabular}{|c|c|c|c|c|c|}
\hline Year & \begin{tabular}{|c} 
Agriculture \\
$\&$ \\
Forestry \\
\end{tabular} & Fishing & Mining & $\begin{array}{c}\text { Transportation } \\
\& \\
\text { Communications }\end{array}$ & Constr. \\
\hline $\begin{array}{l}1969 \\
1971 \\
1976 \\
1981 \\
1986 \\
1989 \\
1992\end{array}$ & $\begin{array}{l}1.35 \\
1.37 \\
1.37 \\
1.24 \\
1.40 \\
1.16 \\
1.27\end{array}$ & $\begin{array}{l}1.81 \\
2.60 \\
2.70 \\
2.58 \\
3.22 \\
3.05 \\
2.31\end{array}$ & $\begin{array}{l}1.98 \\
2.28 \\
2.40 \\
2.23 \\
2.35 \\
2.68 \\
2.39\end{array}$ & $\begin{array}{l}1.11 \\
1.09 \\
1.09 \\
1.07 \\
1.08 \\
1.07 \\
1.04\end{array}$ & $\begin{array}{l}1.17 \\
1.12 \\
1.12 \\
1.27 \\
1.06 \\
1.10 \\
1.03\end{array}$ \\
\hline Year & $\begin{array}{c}\text { Wholesale } \\
\text { Trade }\end{array}$ & Finance & Services & $\begin{array}{c}\text { Public } \\
\text { Administration } \\
\text { Defense }\end{array}$ & $\begin{array}{l}\text { Goods } \\
\text { Producing } \\
\text { Industries }\end{array}$ \\
\hline $\begin{array}{l}1969 \\
1971 \\
1976 \\
1981 \\
1986 \\
1989 \\
1992\end{array}$ & $\begin{array}{l}1.19 \\
1.18 \\
1.13 \\
1.15 \\
1.21 \\
1.15 \\
1.13\end{array}$ & $\begin{array}{l}1.31 \\
1.26 \\
1.23 \\
1.25 \\
1.24 \\
1.24 \\
1.22\end{array}$ & $\begin{array}{l}1.17 \\
1.15 \\
1.17 \\
1.15 \\
1.13 \\
1.11 \\
1.07\end{array}$ & $\begin{array}{l}1.04 \\
1.03 \\
0.99 \\
0.94 \\
0.92 \\
0.92 \\
0.92\end{array}$ & $\begin{array}{r}\text { Unknown } \\
1.35 \\
1.31 \\
1.34 \\
1.30 \\
1.30 \\
1.24\end{array}$ \\
\hline
\end{tabular}

tivity growth in manufacturing activity (Denny and May, 1981). Evidence of convergence in manufacturing output per capita is in concordance with our expectations, since manufacturing is a basic (national) industry which is responsive to inter-regional wage differentials (Bartik 1991; Wasylenko and McGuire 1985); accordingly, mobility of manufacturing capital should ensure that regional wage differentials narrow over time. Further, if manufacturing activity has attained the status of a mature industry in most industrially advanced nations, then one should expect manufacturing to be in the phase of reversal of regional polarization, consistent with Kuznets' U-curve hypothesis.

- Unlike the U.S. experience, Canadian provinces seem to have converged throughout-including the 1980 s-especially in the "new leading industries" such as Finance, Transportation and Communications and Wholesale Trade which, by contrast, were the engines for U.S. regional economic divergence (re-polarization) in the 1980s (Amos 1991). It is interesting to note, therefore, that earlier studies had found that, even by the late 1970s, there existed significant provincial differences in the rate of adoption of new technology (Martin et al 1979; Economic Council of Canada 1977) as well as in capital per worker (Auer 1979), with the At- 
lantic provinces consistently lagging the rest of the country. If so, the observed convergence of the leading sectors of the economy may reflect growing regional diffusion of technology in Canada. However, it may also be due to growing public investments. We return to this issue below.

\section{CANADA'S REGIONAL ECONOMIC DYNAMICS: IMPACT OF PUBLIC POLICY}

Public policy, when it is explicitly or implicitly regionally oriented, can have profound impacts on regional economic well-being. The impact of regional public policy may be captured in two ways. First, one must recognize that the impact of public tax-transfer policies on regional economic welfare is not fully reflected by market-based income measures such as GDP per capita used in this study. Second, part of the provincial GDP per capita convergence found in this paper may reflect the impact of regional policies-in particular, regional economic development policies. We address each of these in turn.

\section{Regional Tax-Transfer Policies and Impact on Provincial Welfare}

Given Canada's historic emphasis on tax and transfer-induced regional equalization policies, other studies have used alternative measures of regional incomes-personal income per capita (market income adjusted for transfers to individuals), disposable income per capita, and disposable income per household (Mansell and Copithorne 1986; Courchene 1981; Abouchar 1971; Chernick 1966). There is evidence that the combination of income taxes and federal transfers have historically resulted in Canadian provincial per capita disposable incomes converging at a faster rate than provincial per capita market incomes (Abouchar 1971; Chernick 1966); the U.S. experience is similar. ${ }^{9}$

While measures of provincial income disparity based on market income per capita continue to be greater than those based on personal or disposable income per capita, the former have recently narrowed at approximately the same rate (based on evidence for 1971-81) as welfare-based measures of provincial disparities (Mansell and Copithorne 1986). Indeed, it is argued that the tax-transfer system may have created a "transfer dependency" which limits market adjustments of the type that would otherwise narrow regional economic disparities without public policy intervention (Courchene 1981). 


\section{Canada's Regional Development Efforts: Impact on Market Income}

Regional public policy can take the form not only of tax-transfer programs directed towards individuals and provincial governments ${ }^{10}$-allowing governments of the less affluent provinces to maintain welfare, education, and health spending at levels not otherwise sustainable by provincial market incomes and tax capacities-but also of programs that offer tax and other incentives to private enterprise. Canada's regional development efforts have come to be institutionalized in the form of relatively new regional development agencies like the Department of Regional Industrial Expansion (DRIE) which were expected to use a range of new policy initiatives such as tax incentives as well as public expenditures to improve economic infrastructure, especially in the four Atlantic provinces (Hansen, Higgins, and Savoie 1990). Despite scepticism about the effectiveness of these agencies (Hansen et al 1990), some verifiable measures such as entrepeneurship and growth indices for the Atlantic provinces have shown encouraging trends in recent years (Savoie 1992).

\section{Measuring the Impact of Regional Policy on Economic Convergence}

While it is difficult to accurately assess the impact of federal regional policies on provincial economic convergence in Canada, we conduct a preliminary investigation based on the limited data available. In particular, we wish to examine if convergent tendencies of the 1980 s in Canada are systematically related to broad trends in federal transfers to the provinces, for equalization of provincial government expenditures or for regional development.

Data on federal transfers to provincial and local governments were obtained for recent years-1986, and 1992. We focus on these years, since the observed Canadian regional convergence of the 1980 s, especially the late 1980 s, is in direct contrast to the regional economic divergence in the United States during the same period, and therefore of greater interest. Second, it was in the mid-80s that DRIE was given new mandates to promote regional economic development noted above.

To examine the impact of federal transfers on economic convergence, aggregate dollar transfers are adjusted by provincial population in the corresponding year to derive per capita amounts. The provinces are then combined on the basis of their convergence (divergence) pattern during the 1980s. These estimates are presented in Table 5.

As can be seen, in the 1980s the upwardly convergent provinces (the four Atlantic provinces - New Brunswick, Nova Scotia, Newfoundland, and Prince Edward Island, as well as Manitoba and Quebec) have been the prime beneficiaries 


\section{TABLE 5}

Panel A: Per Capita Federal Transfers and 1980s Convergence:

A Cross-Classification of Provinces

(Canadian \$)

\begin{tabular}{c|c|c|c|c}
\hline \hline & $\begin{array}{c}\text { Downward } \\
\text { Divergent } \\
\text { (NONE) }\end{array}$ & $\begin{array}{c}\text { Downward } \\
\text { Convergent } \\
\text { (SASK, ALTA, BC) }\end{array}$ & $\begin{array}{c}\text { Upward } \\
\text { Convergent } \\
\text { (NFDL, PSI, NS, } \\
\text { NB, QUE, MAN) }\end{array}$ & $\begin{array}{c}\text { Upward } \\
\text { Divergent } \\
\text { (ONTARIO) }\end{array}$ \\
\hline 1986 & --- & 683 & 1,079 & 509 \\
\hline 1992 & --- & 909 & 1,379 & 677 \\
\hline Growth Rates & --- & $33 \%$ & $28 \%$ & $33 \%$ \\
\hline
\end{tabular}

Panel B: Per Capita 1992 Federal Expenditures on Transportation Infrastructure and Economic Convergence in the 1980s: A Cross-Classification of Provinces (Canadian \$)

\begin{tabular}{c|c|c|c}
\hline \hline $\begin{array}{c}\text { Upward } \\
\text { Convergent } \\
\text { Atlantic } \\
\text { Provinces Only* } \\
\text { (NFDL, PSI, NS, } \\
\text { NB) }\end{array}$ & $\begin{array}{c}\text { Downward } \\
\text { Convergent } \\
\text { (SASK, ALTA, BC) }\end{array}$ & $\begin{array}{c}\text { Upward } \\
\text { Convergent } \\
\text { (NFDL, PSI, NS, } \\
\text { NB, QUE, MAN) }\end{array}$ & $\begin{array}{c}\text { Upward } \\
\text { Divergent } \\
\text { (ONTARIO) }\end{array}$ \\
\hline 328 & & & \\
\hline \hline
\end{tabular}

*Column refers only to the Atlantic provinces among the 6 upwardly convergent provinces (Column 3).

of federal transfers to provincial governments for regional equalization, in terms of the level of per capita transfers received. However, between 1986 and 1992, per capita federal transfers to provincial governments in these upwardly convergent states grew from $\$ 1,079$ to $\$ 1,379$, an increase of 28 percent. By contrast, corresponding transfers to the three downwardly divergent provinces of the eighties (Alberta, British Columbia, and Saskatchewan), grew by 33 percent. Per capita transfers to the only upwardly divergent province, Ontario, grew by 33 percent as well.

The evidence suggests that, while per capita federal transfers do reflect the current economic-and fiscal ${ }^{11}$-conditions of the provinces, ${ }^{12}$ growth in these transfers over the latter part of the 1980s does not seem to bear any relationship to income growth in these provinces. Indeed, it may be argued that these transfers serve in part a cyclical stabilization purpose by relieving fiscal pressures on provinces (see footnote 10); accordingly, federal transfers to provinces are neither intended to nor do they have any secular equalization benefits. 


\section{Impact of Transportation Investments on Regional Equality}

As evidence presented earlier suggests, regional incomes per capita in the Transportation and Communications sector of the Canadian economy continued to converge even during the 1980s. This is in sharp contrast to the U.S. experience, where this industry was characterized by regional polarization during that period. It is plausible that the convergence in transportation activity may reflect not the influence of market forces but rather, the impact of publicly financed expenditures in transportation-infrastructure. To the degree that these programs are regionally heterogeneous, they are expected to have differential regional income impacts. ${ }^{13}$

To examine the impact of infrastructure investment on regional convergence, we use recent data that reflect expenditures on highways and bridges, as part of the 1988 National Transportation Act of Canada; this Act aimed partly to promote economic competition across regions. We examine per capita infrastructural investments for the four groups of provinces used above. As Table 5 indicates, per capita expenditures in the upwardly convergent states equaled $\$ 226$, compared to $\$ 289$ in the downwardly convergent provinces, and $\$ 220$ in the upwardly divergent province, Ontario. These figures do, however, disguise intra-group differences-per capita infrastructural expenditures in the upwardly convergent provinces equal $\$ 328$ if one looks only at the Atlantic provinces; they were clear beneficiaries of recent transportation infrastructural expenditures.

If the differentially favorable infrastructural investments in the Atlantic provinces have had favorable impacts on productivity growth in their economy, it would be consistent with recent evidence on the positive relationship between a country's/state's infrastructural expenditure and its productivity growth (Aschauer 1989; Carlino and Voith 1992). However, absent more data, it is difficult to claim these infrastructural investments alone can adequately account for the overall convergence in economic activity ${ }^{14}$ in Canada in the 1980 s.

\section{CONCLUDING REMARKS}

Canada was characterized by continued regional convergence in the 1980 s, and in sectors such as Transportation and Communications, Finance, and Wholesale Trade, which were the engines of regional re-polarization in the United States during the 1980s. The continued regional convergence in Canada was led by the strong economic performance of the Atlantic provinces and Quebec during the last decade, despite the adverse impact on the former of falling prices and on the latter of quotas in the fishing industry, especially in the late eighties and early 
nineties. The Atlantic provinces apparently compensated for this shortfall by suitably diversifying and with especially strong economic growth in non-traditional sectors such as Transportation and Communications, and in Construction activity. Although not as strong, the "have-not" Atlantic provinces also registered relative improvements in productivity in Finance, Services, and Wholesale Trade. At the same time, growth in the latter set of industries in their traditional growth poles-British Columbia, Alberta, and Ontario-slowed somewhat.

On the basis of available evidence, we cannot conclude that Canada's unique program of federal transfers to provinces in economic and fiscal distress has any implications for long-term regional trends. However, recently initiated programs of transportation-infrastructure investments, even though not explicitly regional in intent, have been disproportionately beneficial to the Atlantic provinces, and may have been partly responsible for the upward convergence of these provinces in the related Transportation and Communications and Construction sectors. Further research should try to focus on more micro-based measures of regional diffusion of technology-such as the regional rate of innovations-in leading technological sectors such as Transport and Communications.

Finally, one should recognize that regional linkages of some Canadian provinces are likely to transcend national boundaries. With increasingly greater mobility of capital between the U.S. and Canada (and, indeed, Mexico), regional convergence is perhaps best examined without imposing the artificial barrier of national boundaries. Nevertheless, the Canadian experience shows that regional re-polarization of economic activity in mature economies is not inevitable.

\section{REFERENCES}

Abouchar, A. "Regional Welfare and Measured Income Differentials in Canada." Review of Income and Wealth 17 (1971):363-69.

Amos, O. "An Inquiry into the Causes of Increasing Regional Income Inequality in the United States." The Review of Regional Studies 19 (1989): (2), 1-13.

Amos, O. "Divergence of Per Capita Real Gross State Product by Sector-1963 to 1986." The Review of Regional Studies 21 (1991): 221-234.

Aschauer, David. "Is Public Expenditure Productive?" Journal of Monetary Economics 23 (1989): 177-200.

Auer, L.Regional Disparities of Productivity and Growth in Canada. Study prepared for the Economic Council of Canada; Ottawa: Minister of Supply and Services Canada (1979). 
Barff, R.A., and P.L. Knight III. "Military Spending, High Technology Industry, and the Timing of the New England Economic Turnaround." Papers, Regional Science Association 65 (1988): 151-166.

Barro, R., and Sala-i-Martin, X. Convergence Across States and Regions, Brookings Papers on Economic Activity 1 (1991): 107-182.

Bartik, T.J. Who Benefits From State and Local Economic Development Policies ? Appendix 2.4 (1991): 254-258. W.E. Upjohn Institute for Employment Research, Kalamazoo, Michigan.

Braun, D. "Income Inequality and Economic Development: Geographic Divergence." Social Sciences Quarterly 75 (1991): 520-536.

Canada Yearbook. Statistics Canada, (1994): Ontario, Canada.

Canadian Economic Observer. Statistics Canada, (1993): Ontario, Canada.

Carlino, Gerald and Richard Voith. "Accounting for State Differences in Aggregate State Productivity," Regional Science and Urban Economics 22 (1992): 597-617.

CBOC Provincial History. Conference Board of Canada (1994): Ontario, Canada. Chernick, S. Interregional Disparities in Income. Economic Council of Canada Staff Study 14 (1966): Ottawa: Queen's Printer.

Coughlin, C., and Mandelbaum, T.B. "Why Have State Per Capita Incomes Diverged Recently?" Review of the Federal Reserve Bank of St. Louis, 70 (1988): 24-37.

Courchene, T. A Market Perspective on Regional Disparities. Canadian Public Policy 7 (1981):506-18.

Crowell, T. "Economic and Financial Performance of Canada's Provinces." Moody's Municipal Issues, 5 (1988): 3,4,7.

Denny, M., and J. May. "Intertemporal Changes in Regional Productivity in Canadian Manufacturing." Canadian Journal of Economics 14 (1981):390408.

Economic Council of Canada. Living Together: A Study in Regional Disparities. Ottawa: Minister of Supply and Services, Canada (1977).

Fan, C.C., and E. Casetti. "The Spatial and Temporal Dynamics of U.S. Regional Income Inequality, 1950-1989." The Annals of Regional Science 28:2 (1994): 177-196.

Friedenberg, H.L. "Regional Differences in Personal Income Growth, 1929-77." Survey of Buying Power, October, (1978): 27-31.

Garnick, D.H. "Accounting for Regional Differences in Per Capita Personal Income Growth: An Update and Extension." Survey of Current Business 70 (1990): 29-40. 
Garnick, D.H., and H.L. Friedenberg. "Accounting for Regional Differences in Per Capita Personal Income Growth, 1929-79." Survey of Buying Power, September (1982): 24-34.

Hansen, N., B., Higgins, and D. Savoie. Regional Policy in a Changing World, Plenum Press, New York, NY (1990).

Krugman, P. "First Nature, Second Nature, and Metropolitan Location." Journal of Regional Science (1993): 129-144.

Kuznets, S. "Economic Growth and Income Inequality." The American Economic Review 45 (1955): 1-28.

Lampe, D. (ed.). The Massachussets Miracle: High Technology and Economic Revitalization, MIT Press, Cambridge, Mass. (1988).

Mallick, R., and E. Carayannis. Regional Economic Convergence in Mexico: An Analysis by Industry, Growth and Change 25 (1994) (Summer): 325-334.

Mallick, R. Convergence of State Per-Capita Incomes: An Examination of its Sources, Growth and Change 24 (1993) (Summer): 321-340

Mansell, R., and L. Copithorne. "Canadian Regional Economic Disparities: A Survey." In Norrie, K (ed), Disparities and Interregional Adjustment, University of Toronto Press, Toronto (1986): 1-51.

Martin F., N. Swan, I. Banks, G. Barker, and R. Beaudry. The Interregional Diffusion of Innovations in Canada. Study prepared for the Economic Council of Canada. Otawa: Minister of Supply and Services, Canada (1979).

Maxwell, P. "Trends in Regional Income Disparities: An Australian Perspective on the Canadian Experience," Canadian Journal of Regional Science, forthcoming.

Maxwell, P., and Hite, J.C. "The Recent Divergence of Regional Per Capita Incomes: Some Evidence from Australia." Growth and Change, Winter 1992 (1992): $37-51$.

McCombie, J.S.L. "A Synoptic View of Regional Growth and Unemployment: The Neoclassical Theory." Urban Studies, 25 (1988): 267-281.

Nissan, E., and G. Carter. "Income Inequality Across Regions Over Time." Growth and Change 24 (1993): 303-319.

Reid, C. (1989). Classical Economic Growth, Oxford, UK, Basil Blackwell.

Richardson, H., and J. Turek. "The Scope and Limits of Federal Intervention." In H. Richardson, and J. Turek (eds), Economic Prospects for the Northeast, Temple University Press, Philadelphia (1985).

Savoie, D. Regional Development Policy: Canada's Search for Solutions. 2nd ed., Toronto University Press, Toronto (1992).

Smith, D.M. "Neoclassical Growth Models and Regional Growth in the U.S." Journal of Regional Science 15 (1975): 165-181. 
Turek, J.H. "The Northeast in a National Context: Background Trends in Population, Income, and Employment." In H. Richardson, and J. Turek (eds), Economic Prospects for the Northeast. Temple University Press, Philadelphia (1985).

Wasylenko, M., and McGuire, T. "Jobs and Taxes: The Effect of Business Climate on States' Employment Growth Rates." National Tax Journal, 4 (December) (1985): 497-512.

\section{ENDNOTES}

1. For example, federal government tax incentives for economic development of inner cities, or direct grants to local governments for crime prevention or housing result in regional income redistribution, even though targeted for specific programs (Richardson and Turek 1985).

2. A similar approach to measuring the strength of the convergence relationship across U.S. regions is adopted by Turek (1985). The goodness of fit approach is especially appropriate for a relatively small sample of regions/states where inferences from regression analyses are not defensible.

3. Incomplete data for 1961-1992 for Yukon and The Northwest Territory led us to exclude them from the study. The remaining ten provinces of Canada are denoted as: Newfoundland (NFDL), Prince Edward Island (PEI), Nova Scotia (NS), New Brunswick (NB), Saskatchewan (SASK), Manitoba (MAN), Quebec (QUE), Ontario (ONT), Alberta (ALTA), and British Columbia (BC).

4. The evidence of declining regional disparities in LFP rates in Canada is parallelled by the reported evidence on the U.S. experience in this regard (Mallick 1993).

5. Although not reported for brevity in Table 3, convergence in Finance activity was also reflected in the relative decline in PPCI of two other states with high initial per capita incomes in this industry-British Columbia and Ontario.

6. The increased regional inequality within these industries during the former period was due primarily perhaps to the unparalleled economic growth in provinces like British Columbia, which benefited from higher oil and gas prices; Saskatchewan, which benefited from higher agricultural, mineral, and oil prices; and the Atlantic provinces, which gained from growth of fishing exports. In the latter period, the Atlantic provinces have been hurt by quotas and lower prices in fishing, and Saskatchewan has been hurt by restrictions on mineral exports (Crowell 1988). 
7. It is interesting that the "primary" or "extraction-based" industries are among the ones that have been non-convergent in the U.S. (Amos, 1991) as well as in Mexico (Mallick and Carayannis 1994).

8. Decline in manufacturing inequality has occurred due to a decline in the manufacturing PPCI of traditional manufacturing provinces such as Alberta, Ontario, and Quebec and an increase in the manufacturing PPCI of Manitoba and the Atlantic provinces (results available upon request).

9. In the United States, the relatively high-income Northeast and Pacific states have traditionally contributed more to federal taxes per capita than they have received in the form of benefits, while Southern states have been net beneficiaries of individual income redistribution policies (Richardson and Turek 1985).

10. Canada has historically-since the time of its Confederation in 1867-had a program of federal transfers to provincial governments to achieve regional equalization. The Equalization Program is based on a formula whereby the federal government, out of its general revenues, compensates those provinces that have per capita revenues below the representative average standard (Canada Yearbook 1994)

11. The explicit purpose of transfers under the equalization program is to provide the "have-not" provinces with federal transfers enough to ensure levels of services that do not unduly burden their tax capacities (Crowell 1988).

12. Note that the per capita transfers to the provinces with below-average income levels during the 1980 s-i.e., the upwardly convergent provinces-were consistently greater in levels than transfers to the above-average (downwardly convergent and upwardly divergent) provinces.

13. In a study with international scope, Aschauer (1989) has shown that there is a significant positive relationship between government investments in infrastructure and growth of productivity and income.

14. The differentially greater infrastructural investments in the Atlantic states may have had some sectoral effects, however. In Construction activity, Prince Edward Island, which ranked at the bottom in terms of its PPCI (per capita income at 68 percent of national average) in this sector in 1971, had attained fifth (median) rank in 1992, with per capita income as high as 90 percent of the national average in this industry. A similar, albeit more modest, pattern of upward convergence of the Atlantic provinces emerges when we look at the Transportation and Communications industry: Nova Scotia, which ranked at the bottom in terms of PPCI in 1971, had moved up to ninth place by 1992. 